TITLE:

\title{
Small-molecule inhibitors of SREBP activation - potential for new treatment of metabolic disorders
}

\author{
$\operatorname{AUTHOR}(\mathrm{S}):$
}

Watanabe, Mizuki; Uesugi, Motonari

\section{CITATION:}

Watanabe, Mizuki ... [et al]. Small-molecule inhibitors of SREBP activation - potential for new treatment of metabolic disorders. MedChemComm 2013, 4(11): 1422-1433

ISSUE DATE:

2013-08-19

URL:

http://hdl.handle.net/2433/192998

\section{RIGHT:}

(c) The Royal Society of Chemistry 2013; This is not the published

version. Please cite only the published version.; この論文は出版社版で ありません。引用の際には出版社版をご確認ご利用ください。 


\title{
Small-molecule Inhibitors of SREBP Activation - Potential for New Treatment of Metabolic Disorders
}

\author{
Mizuki Watanabe and Motonari Uesugi* \\ Received (in $X X X, X X X)$ ) $X$ th $X X X X X X X X X 20 X X$, Accepted $X$ th $X X X X X X X X X 20 X X$ \\ DOI: 10.1039/b000000x
}

\begin{abstract}
Sterol regulatory element-binding proteins (SREBPs) are transcriptional factors that control lipid and cholesterol metabolism. Activation of SREBPs in response to a decrease in the cellular sterols results in acceleration of the synthesis of fatty acids, triglycerides, and cholesterol. Aberrant SREBP activity has been linked to metabolic disease states, such as obesity, fatty liver, insulin resistance, hyperlipidemia, and 10 atherosclerosis. Thus, inhibition of SREBP activation is a potential therapeutic approach to treating metabolic disorders. This review focuses on direct or indirect small-molecule inhibitors of SREBP activation.
\end{abstract}

\section{Introduction}

Sterol regulatory element-binding proteins (SREBPs) are one of 15 the most important families of transcription factors involved in lipid homeostasis. SREBPs control cellular metabolism in all tissues by regulating the expression of the genes related to biosynthesis and uptake of fatty acids, triglycerides, cholesterol, and phospholipids. ${ }^{1,2}$ The central roles of SREBPs in lipid 20 metabolism link them tightly to metabolic syndromes. For example, high insulin levels, induced by high calorie diets or obesity, hyper-activate SREBPs, causing triglyceride accumulation and inducing fatty liver diseases. ${ }^{3,4}$ Hyperactivation of SREBPs also increases cholesterol levels and 25 suppresses insulin receptor substrate (IRS)-2, leading to hyperlipidemia, arteriosclerosis, and insulin resistance., Furthermore, activation of SREBPs is often correlated with the growth of cancers and the ability of hepatitis virus to cause fatty liver diseases. ${ }^{7,8}$ The involvement of SREBP activation in the 30 multiple diseases has made these transcription factors attractive pharmaceutical targets. ${ }^{9}$ This review summarizes recent studies of small molecules that directly or indirectly suppress the cellular functions of SREBPs.

\section{Regulation of SREBP pathway}

\section{${ }_{35}$ The SREBP family}

In mammals, the SREBP family consists of three isoforms, SREBP-1a, -1c, and -2 , which play overlapping, but distinct, roles. ${ }^{1}$ SREBP-1a, which usually exists in proliferating cells, promotes the synthesis of fatty acids and cholesterol. In contrast, ${ }_{40}$ SREBP-1c is expressed mainly in the liver, and primarily stimulates fatty acid and triglyceride synthesis by inducing transcription of the genes necessary to convert acetyl CoA into fatty acids and triglycerides, e.g., fatty acid synthase (FAS), stearoyl-CoA desaturase 1 (SCD-1), and acetyl-CoA carboxylase
${ }_{45}$ (ACC). ${ }^{10}$ SREBP-2 is also expressed in the liver, and primarily activates genes involved in cholesterol synthesis and uptake, including 3-hydroxy-3-methylglutaryl-CoA reductase (HMGCR), and low-density lipoprotein receptor (LDLR). ${ }^{2}$

\section{The synthesis of SREBP}

50 SREBPs are basic helix-loop-helix leucine zipper (bHLH-LZ) transcription factors. SREBP-1a and -1c are encoded by a single gene and generated by an alternative splicing of exon $1 .{ }^{11}$ The expression of SREBP-1c gene is self-controlled, and is stimulated by both insulin and oxysterols through activation of the nuclear ${ }_{55}$ hormone receptor, liver X receptor (LXR). ${ }^{12-14}$ When stimulated by insulin, LXR heterodimerizes with retinoid $X$ receptor (RXR). The heterodimer interacts with LXR-responsive elements located in the SREBP-1c promoter, stimulating transcription of the SREBP-1c gene. ${ }^{13}$ SREBP-2 is encoded by another gene, whose ${ }_{60}$ splicing variants have not been discovered. ${ }^{11}$

\section{The proteolytic activation of SREBP}

Unlike other transcription factors in the bHLH-LZ family, SREBPs are newly synthesized on the endoplasmic reticulum (ER) membrane as inactive precursors (Fig. 1). ${ }^{14}$ On the ER, The ${ }_{65}$ C-terminal domain of SREBPs binds to SREBP cleavageactivating protein (SCAP). The SREBP-SCAP complex is transported from the ER to the Golgi apparatus via COPII vesicles (Fig. 1A). In the Golgi apparatus, SREBPs are sequentially cleaved by two proteases: site-1 protease (S1P), a 70 membrane-bound serine protease also known as SKI-1; and site-2 protease (S2P), a $\mathrm{Zn}^{2+}$ metalloprotease, and the $\mathrm{N}$-terminal domains of SREBPs, which are transcriptionally active fragments of SREBPs, are generated.

SCAP is an indispensable protein for SREBP activation, both 75 in vitro and in vivo. In addition to acting as an escort protein for SREBPs, physical association with SCAP seems to stabilize SREBPs. In SCAP-deficient CHO cells, both the precursor and the nuclear form of SREBPs disappear. ${ }^{15}$ Without SCAP, 


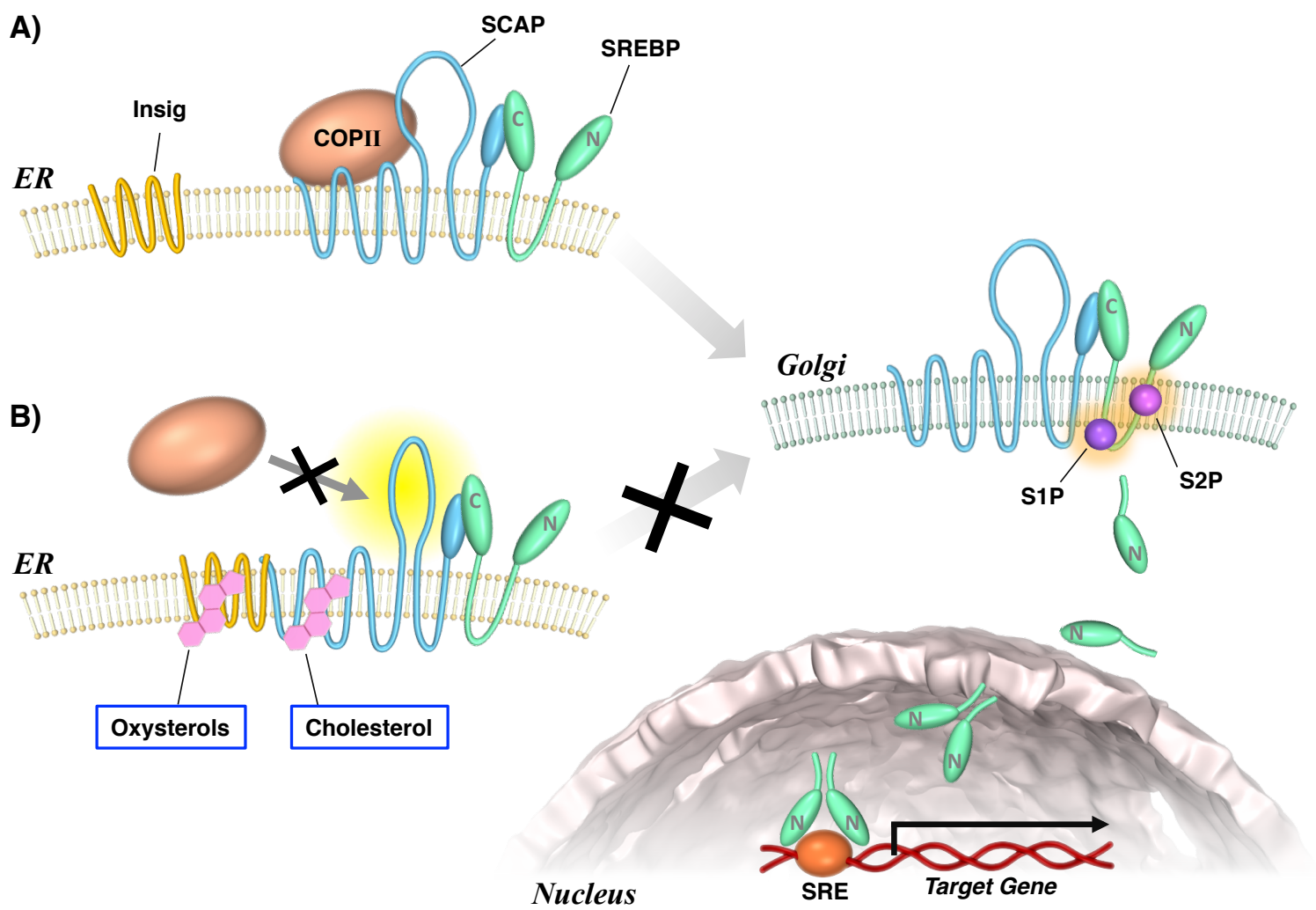

Fig. 1 The pathway of SREBP activation.

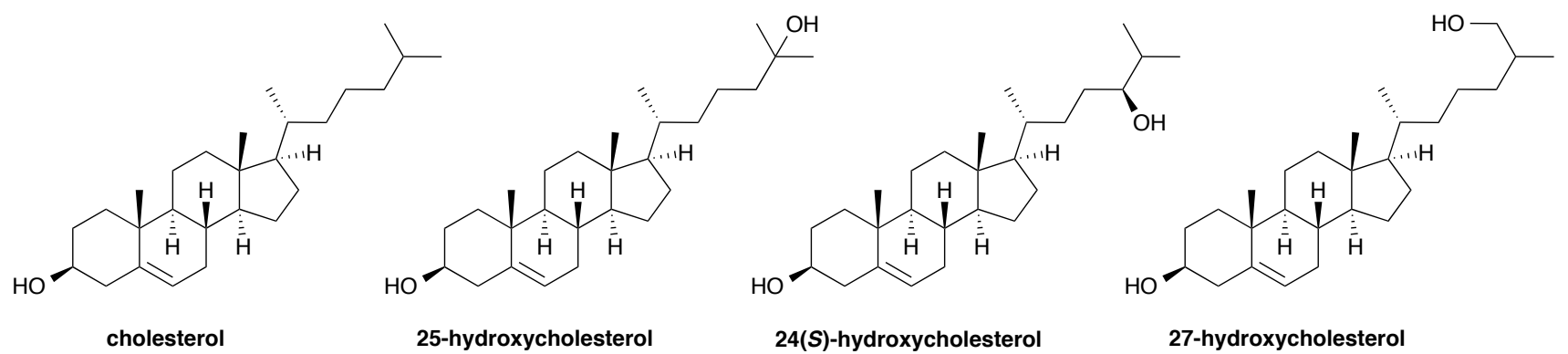

Fig. 2 Chemical structures of cholesterol and oxysterols

${ }_{5}$ SREBPs in the ER are unstable and cannot translocate to the Golgi apparatus. In hepatic SCAP-deficient mice, basal rates of cholesterol and fatty acid synthesis in the liver were reduced by $80 \%$, due to decreases in mRNAs that encode multiple biosynthetic enzymes. ${ }^{16}$

10 The proteolytic activation of SREBP is tightly regulated by a negative feedback loop with cholesterol, in which the ER-resident proteins, Insig-1 and Insig-2, play an important role. ${ }^{2,17}$ When cellular sterol levels are high, cholesterol (Fig. 2) binds to SCAP, and 25-hydroxycholesterol (Fig. 2), a metabolite of cholesterol, 15 binds to the Insig proteins. ${ }^{18,19}$ The binding of cholesterol to SCAP, or of 25-hydroxycholesterol to Insig proteins, stimulates formation of an SREBP-SCAP-Insig complex (Fig. 1B). The binding of Insig protein to SCAP blocks the interaction of SCAP with COPII, so that the SREBP-SCAP complex is retained in the ${ }_{20} \mathrm{ER}^{20}$ Thus, excess sterols inhibit translocation of the SREBPSCAP complex to the Golgi apparatus, and activation of SREBPs is blocked.

In addition to 25-hydroxycholesterol, other oxysterols that are generated under excess cholesterol conditions, such as 24(S)25 hydroxycholesterol and 27-hydroxycholesterol (Fig. 2), block the processing of SREBPs, especially SREBP-2, by the same mechanism as that of 25-hydroxycholesterol. ${ }^{19}$

\section{The regulation of the nuclear form of SREBP}

The cleaved SREBP N-terminal domains (the nuclear form of ${ }_{30}$ SREBP) are released from the membrane of the Golgi apparatus and transferred to the nucleus, where they bind to the promoter 


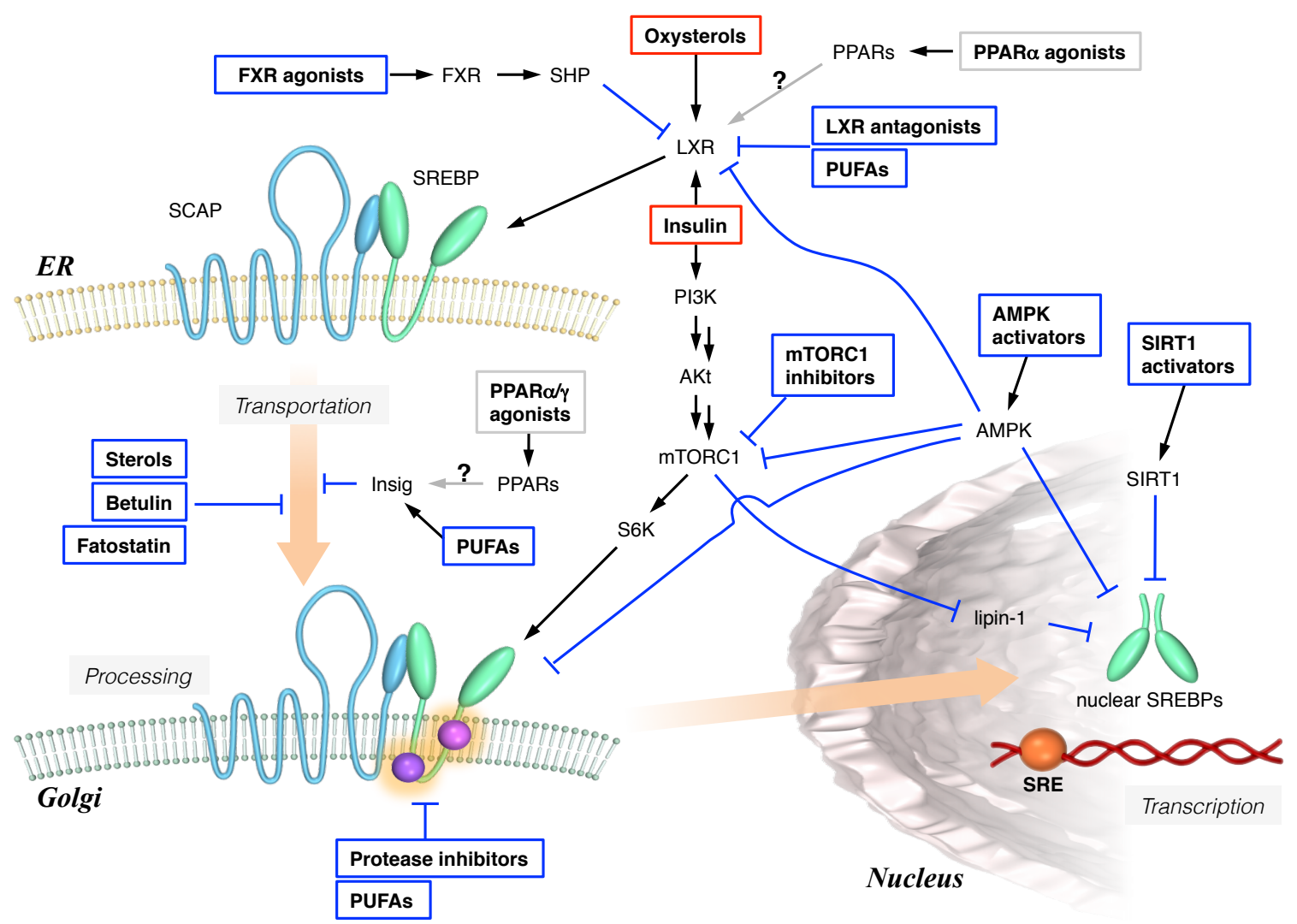

Fig. 3 Multiple regulation of SREBP activation by small molecules.

motifs known as sterol regulatory elements (SREs) as dimers. ${ }^{11}$ They promote the expression of all genes encoding the enzymes 5 required to convert acetyl CoA into fatty acids and cholesterol (Fig. 1). ${ }^{2}$

The translocation and stability of the nuclear form of SREBP are controlled by a number of enzymes: a phosphatase, a kinase, and a deacetylase. Insulin, the major activator of SREBP-1c in 10 the liver, promotes the activation of SREBP-1c via multiple pathways. $^{21,22}$ One pathway is via the activation of Akt (also known as protein kinase B) and mammalian target of rapamycin (mTOR) kinase. Insulin activates phosphatidylinositol 3-kinase (PI3K) by inducing phosphorylation of IRS-1/2, promoting the 15 conversion of phosphatidylinositol 4,5-bisphosphate (PIP2) to phosphatidylinositol 3,4,5-trisphosphate (PIP3). PIP3 binds to and activates Akt, which directly phosphorylates tuberous sclerosis complex $1 / 2(\mathrm{TSC} 1 / 2)$ and PRAS40, leading to the activation of mTOR complex 1 (mTORC1). Activated mTORC1 20 phosphorylates lipin-1, a phosphatidic acid phosphatase, and inhibits its translocation to the nucleus. Dephosphorylated, nuclear, catalytically active lipin-1 promotes nuclear remodeling and decreases the nuclear abundance of SREBP-1c. ${ }^{23}$ Therefore, mTORC1 activation would result in increased nuclear SREBP-1c

${ }_{25}$ (Fig. 3). In addition to the lipin-1-mediated regulation of SREBPs, mTORC1 activation has been reported to stimulate proteolytic SREBP-1c processing via activation of p70 S6-kinase (S6K), although the detailed mechanism remains unknown (Fig. 3). ${ }^{24}$

Another enzyme regulating the nuclear SREBP is adenosine 5'-
30 monophosphate-activated protein kinase (AMPK), an important enzyme that monitors cellular energy status. ${ }^{25}$ AMPK, activated in response to cellular metabolic stresses, phosphorylates and inactivates $\mathrm{ACC}$ and HMGCR, key enzymes involved in regulating de novo biosynthesis of fatty acids and cholesterol. ${ }^{26}$ 35 Interestingly, the latter two enzymes are encoded by the target genes of SREBPs, and the activation of AMPK and SREBP-1c in liver is inversely correlated. ${ }^{27}$ Recent studies showed that AMPK directly controls SREBPs: AMPK binds directly to and phosphorylates SREBP-1c or -2 , blocking both the cleavage ${ }_{40}$ processing and the nuclear translocation of SREBPs (Fig. 3). ${ }^{28}$ AMPK also inhibits PI3K/Akt/mTOR signaling, which as mentioned earlier, increases the amounts of nuclear SREBP-1c (Fig. 3). ${ }^{29}$ In addition, AMPK directly inhibits ligand-induced LXR activity on the SREBP-1c gene promoter (Fig. 3), although 45 the detailed mechanism remains unknown. ${ }^{30}$

SIRT1 is an $\mathrm{NAD}^{+}$-dependent deacetylase involved in both glucose and lipid metabolism. ${ }^{31}$ Recent studies have shown that SREBPs are direct targets of SIRT1 (Fig. 3). ${ }^{32,33}$ SIRT1 increases the amounts of deacetylated SREBPs, which are susceptible to so ubiquitin-mediated degradation, decreasing the nuclear SREBPs levels, and, consequently, the expression levels of SREBPresponsive lipogenic genes.

\section{Inhibitors of the synthesis of SREBP}

LXR antagonists 


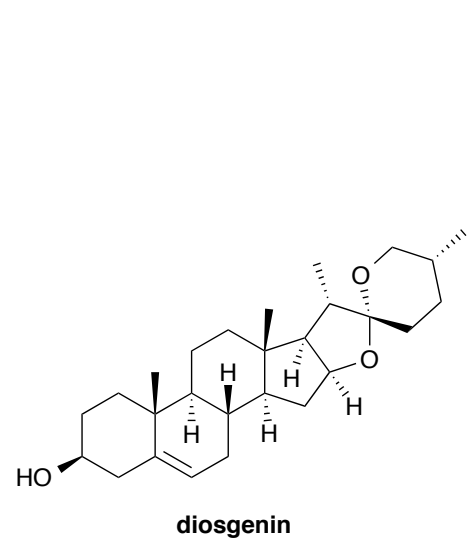<smiles>O=S(=O)(c1ccc(F)cc1)N(Cc1ccccc1)Cc1ccc(-c2cccc(CN3CCNCC3)c2)cc1</smiles>

2<smiles>O=S(=O)(c1ccccc1)N(CC(F)(F)F)c1ccc(C(O)(F)C(F)(F)F)cc1</smiles>

T0901317

Fig. 4 Chemical structures of LXR ligands.

Diosgenin (Fig. 4), an aglycone of fenugreek that functions as an LXR $\alpha$ antagonist, down-regulates expression of SREBP-1c and 5 its downstream genes, including FAS, ACC, and SCD-1, and suppresses triglyceride accumulation in HepG2 cells. $^{34}$ Administration of fenugreek to KK-Ay mice reduced the expression of hepatic SREBP-1c and decreased triglyceride levels in the blood and liver. Similarly, the synthetic LXR antagonists, ${ }_{10}$ GSK2033 and molecule 1 (Fig. 4), reduced the expression of SREBP-1c and triglyceride levels in cultured cells. ${ }^{35,36}$ GSK2033 is a synthetic derivative of a hit molecule (2, Fig. 4) of a highthroughput screening (HTS), ${ }^{35}$ and molecule $\mathbf{1}$ is an antagonist designed from the structure of the known LXR agonist, ${ }_{15}$ T0901317 (Fig. 4). ${ }^{36}$

\section{PUFAs}

Polyunsaturated fatty acids (PUFAs) in fish oil have long been known to inhibit synthesis of fatty acids and triglycerides, and to lower plasma triglyceride levels. ${ }^{37}$ In fact, eicosapentaenoate has 20 been used clinically as a drug for hyperlipidemia. The lipidlowering effects of PUFAs are mediated, in part, by downregulation of the lipogenic function of SREBP-1c in the liver.

PUFAs suppress hepatic SREBP-1c transcriptionally (Fig. 3). Arachidonic acid, eicosapentaenoic acid, and docosahexaenoic 25 acid (Fig. 5) down-regulate the expression of hepatic SREBP-1c by acting as antagonists of LXR $\alpha$, thereby decreasing the expression levels of lipogenic enzymes. ${ }^{38-40}$ Oral administration of fish oil into animal models reduced the mRNA expression of SREBP-1c, as well as triglyceride levels in the liver. ${ }^{41}$

30 In addition to their effects on SREBP-1c, PUFAs are known to be ligands for peroxysome proliferator-activated receptor (PPAR) alpha, ${ }^{42,43}$ a nuclear receptor that controls lipid and glucose metabolism. PUFAs also inhibit the hepatic maturation of carbohydrate-responsive element-binding protein (ChREBP), ${ }^{44}$ a

${ }_{35}$ glucose-activated transcription factor involved in lipogenesis in the liver. Thus, inhibition of SREBP activation is probably only one of multiple mechanisms and targets by which PUFAs exert beneficial effects on metabolic diseases.<smiles>CCCCC/C=C\C/C=C\C/C=C\C/C=C\CCCC(=O)O</smiles>

arachidonic acid<smiles>CC/C=C\C/C=C\C/C=C\C/C=C\C/C=C\CCCC(=O)O</smiles>

eicosapentaenoic acid<smiles>CC/C=C\C/C=C\C/C=C\C/C=C\C/C=C\C/C=C\CCC(=O)O</smiles>

docosahexaenoic acid

Fig. 5 Chemical structures of PUFAs.

\section{PPAR $\alpha$ agonists}

Recent investigation revealed that ligands of the PPAR family of nuclear receptors modulate SREBP activity (Fig. 3). Fibrates, anti-hyperlipidemia PPAR $\alpha$ agonists, down-regulate triglyceride ${ }_{45}$ levels by promoting $\beta$-oxidation of fatty acids, and reduce very low-density lipoprotein (VLDL) levels by increasing adipose differentiation-related proteins. ${ }^{45}$

PPAR $\alpha$ agonists appear to modulate the activity of SREBPs through LXR. Wy14,643 (Fig. 6) is a PPAR $\alpha$ agonist that so prevents LXR ligands from inducing SREBP-1c gene expression in primary rat hepatocytes and in mouse liver. ${ }^{46}$ The activation of PPAR $\alpha$ somehow blocks the ability of the LXR/RXR heterodimer to stimulate promoter activity of SREBP-1c.

In contrast, results of another research on PPAR $\alpha$ agonists 55 reveal a discrepancy. A report claimed that Wy14,643 and GW7647 (another PPAR $\alpha$ agonist, Fig. 6) enhanced activity of the SREBP-1c gene promoter through LXR elements, thereby increasing endogenous SREBP-1c expression in cultured human 
<smiles>Cc1cccc(Nc2cc(Cl)nc(SCC(=O)O)n2)c1C</smiles>

Wy 14,643<smiles>CC(C)OC(=O)C(C)(C)Oc1ccc(C(=O)c2ccc(Cl)cc2)cc1</smiles>

fenofibrate<smiles>CC(C)(Sc1ccc(CCN(CCCCC2CCCCC2)C(=O)NC2CCCCC2)cc1)C(=O)O</smiles>

GW7647

Fig. 6 Chemical structures of PPAR $\alpha$ agonists.

hepatocytes. ${ }^{47}$ Inconsistent results might be due to differences in the species and nutritional status of cells used in the 5 experiments. ${ }^{47}$

\section{FXR agonists}

Farnesoid $\mathrm{X}$ receptor (FXR) is a nuclear receptor whose endogenous agonist is bile acid, a steroid acid composed primarily of cholic acid derivatives that are biosynthesized via 10 oxidation of cholesterol. ${ }^{48}$ The role of FXR in the metabolism of cholesterol, triglyceride, and glucose links it to SREBPs. Activation of FXR by FXR agonists (Fig. 7), such as cholic acid, chenodeoxycholic acid, or the synthetic agonist, GW4064, impairs the expression of SREBP-1c that is induced by high-fat 15 diets or LXR ligands, ultimately decreasing the hepatic and renal levels of triglyceride. ${ }^{49,50}$ The decrease in SERBP-1c expression seems to be mediated by the binding of small heterodimer partner (SHP) to LXR $\alpha$ or other transcription factors that stimulate SREBP-1c expression (Fig. 3). This mechanism could account for 20 the observation that administration of bile acid decreases hepatic secretion of VLDL. ${ }^{50}$

\section{Inhibitors of the proteolytic activation of SREBP}

Sterols inhibit SREBP activation. However, sterols themselves might not be suitable as selective pharmaceuticals for treating 25 metabolic disorders, considering their effects on SREBP-1c along with their other physiological functions. ${ }^{51}$ Especially, oxysterols are endogenous ligands of LXRs, ${ }^{52-54}$ and stimulate the transcription of SREBP-1c via activation of LXR $\alpha$ in the liver (Fig. 3). ${ }^{55}$ By increasing SREBP-1c levels under sterol overload, 30 the LXRs might ensure a sufficient supply of fatty acids to allow storage of excess cholesterol as cholesteryl ester. ${ }^{55}$ Thus, administration of oxysterols could decrease blood cholesterol level by suppressing SREBP-2 activation, and also induce hypertriglyceridemia by accelerating SREBP-1c transcription. ${ }^{56}$<smiles>C[C@H](CCC(=O)O)[C@H]1CC[C@H]2[C@@H]3[C@H](C[C@H](O)[C@]21C)[C@@]1(C)CC[C@@H](O)C[C@H]1C[C@H]3O</smiles>

cholic acid

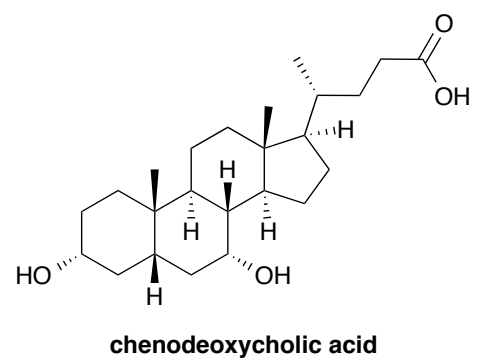<smiles>CC(C)c1onc(-c2c(Cl)cccc2Cl)c1COc1ccc(/C=C/c2cccc(C(=O)O)c2)c(Cl)c1</smiles>

GW4064

Fig. 7 Chemical structures of FXR agonists.

There have been a number of investigations for discovering nonsterol molecules that block the proteolytic activation of SREBP.

\section{Protease inhibitors}

${ }_{40} \mathrm{~S} 1 \mathrm{P}$ and S2P are essential for the proteolytic activation of SREBPs. Rates of fatty acid and cholesterol synthesis were reduced by $75 \%$ in the livers of mice with disrupted S1P gene. ${ }^{57}$ The amounts of the nuclear form of SREBP and the expression levels of its target genes were also dramatically decreased. These 45 observations suggested that S1P inhibitors could be effective as lipid-lowering drugs (Fig. 3).

$\mathrm{S} 1 \mathrm{P}$ is inhibited by the general serine protease inhibitors, 3,4dichloroisocoumarin and 4-(2-aminoethyl)benzenesulfonyl fluoride (AEBSF) (Fig. 8) ${ }^{58,59}$ AEBSF also suppresses generation 50 of the nuclear form of SREBP-2. ${ }^{58}$ However, these inhibitors are not selective for S1P. The peptide, decanoyl-Arg-Arg-Leu-Leuchloromethylketone (Dec-RRLL-CMK, Fig. 8), is an irreversible S1P inhibitor that is more selective than AEBSF for $\mathrm{S} 1 \mathrm{P},{ }^{60}$ and impairs the maturation of SREBP-1/-2 in cultured cells. ${ }^{61}$

55 PF-429242 (Fig. 8), a non-peptidic, reversible, and highly selective inhibitor of $\mathrm{S} 1 \mathrm{P}\left(\mathrm{IC}_{50}=0.17 \mu \mathrm{M}\right)$ was discovered by a research group at Pfizer, Inc. ${ }^{62}$ This aminopyrrolidineamide derivative was derived from a hit molecule (3) of a HTS using purified human S1P. PF-429242 inhibits the processing of ${ }_{60}$ SREBP-2 and suppresses the expression of SREBP target genes in cultured cells. ${ }^{63}$ Hepatic rates of cholesterol and fatty acid synthesis were reduced in mice treated with PF-429242.

Inhibitors of S2P have also been reported. The metalloprotease inhibitor, 1,10-phenanthroline (Fig. 8), shows dose-dependent ${ }_{65}$ inhibitory effects on the protease activity of S2P. ${ }^{64}$ Nelfinavir 
<smiles>O=c1oc(Cl)c(Cl)c2ccccc12</smiles>

3,4-dichloroisocoumarin<smiles>NCCc1ccc(S(=O)(=O)F)cc1</smiles>

AEBSF<smiles>CCN(CC)Cc1ccc(C(=O)N(CCc2ccccc2OC)[C@H]2CCNC2)cc1</smiles>

PF-429242<smiles>CC(C)Oc1ccc(C(=O)N(CCc2ccccc2Cl)C2CCNC2)cc1</smiles>

3<smiles>CCCCCCCCCC(=O)N[C@@H](CCCNC(=N)N)C(=O)N[C@@H](CCCNC(=N)N)C(=O)N[C@@H](CC(C)C)C(=O)N[C@@H](CC(C)C)C(=O)CCl</smiles><smiles></smiles>

1,10-phenanthroline<smiles>Cc1c(O)cccc1C(=O)N[C@H](CSc1ccccc1)[C@@H](O)CN1C[C@@H]2CCCC[C@H]2C[C@H](C(=O)NC(C)(C)C)[C@H]1C</smiles>

nelfinavir

Dec-RRLL-CMK

Fig. 8 Chemical structures of S1P and S2P inhibitors.

(Fig. 8), a human immunodeficiency virus (HIV) protease inhibitor, inhibits S2P activity, and also down-regulates the 5 processing of SREBP-1 and the expression of FAS in cultured cells. ${ }^{65,66}$

S1P and S2P are major enzymes controlling cholesterol and fatty acid synthesis, but are also involved in several homeostatic functions, such as the ER stress response, bone mineralization, 10 and targeting of proteins to lysosomes. ${ }^{67}$ Dec-RRLL-CMK and nelfinavir exhibit cytotoxicity, ${ }^{65,68}$ possibly due to impaired processing of activating transcription factor 6 (ATF6), another substrate of S1P and S2P that is involved in the stress response. ${ }^{60,}$

${ }^{65}$ Thus, chronic use of S1P and S2P inhibitors might cause a 15 range of side effects. ${ }^{67}$

\section{Inhibitors of SREBP-SCAP migration}

Two non-endogenous molecules that selectively inhibit SREBP activation have been discovered through chemical library screening. ${ }^{69,70}$ Both fatostatin and betulin (Fig. 9) inhibit 20 migration of the SREBP-SCAP complex to the Golgi apparatus by directly binding to SCAP, and thereby down-regulate expression of the genes involved in cholesterol and fatty acid synthesis (Fig. 3).

Fatostatin was the first discovered non-endogenous molecule 25 that inhibits SREBP-SCAP migration. Fatostatin, a synthetic small molecule with a non-steroidal structure, was originally described as an inhibitor of the insulin-stimulating differentiation of 3T3-L1 cells to adipocyte. ${ }^{71}$ Administration of fatostatin by intraperitoneal injection blocked increases in body weight, blood 30 glucose, and hepatic fat accumulation in $o b / o b$ mice, even under uncontrolled food intake. ${ }^{69}$ A structure-activity relationship study of fatostatin derivatives led to the discovery of FGH10019 (Fig. 9), a potent inhibitor of SREBP activation with drug-like physical properties. ${ }^{72} \mathrm{Ob} / \mathrm{ob}$ mice fed normal chow containing FGH10019

35 exhibited reduced body weight, serum cholesterol levels, and triglyceride levels in the liver, compared to controls.<smiles>CCCc1cc(-c2nc(-c3ccc(C)cc3)cs2)ccn1</smiles><smiles>CCCc1cc(-c2nc(-c3ccc(NS(C)(=O)=O)cc3)cs2)ccn1</smiles>

FGH10019

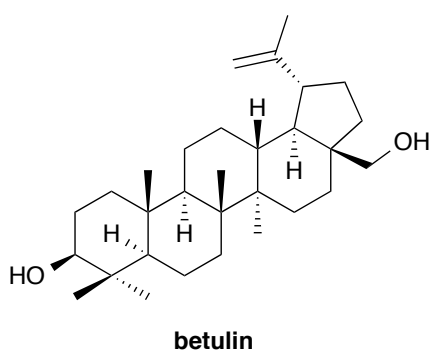

Fig. 9 Chemical structures of inhibitors of SREBP-SCAP migration.

More recently, betulin, a pentacyclic triterpene which is a 40 natural product abundant in birch bark, was identified to inhibit SREBP processing in a human hepatoma cell line. ${ }^{70}$ Mice fed a western-type diet, then treated with betulin through gastric irrigation, exhibited decreased lipid levels in serum and tissues, and increased insulin sensitivity. Administration of betulin to ${ }_{45}$ LDLR-knockout mice, an atherosclerosis disease model, reduced the size and improved the stability of atherosclerotic plaques.

The small molecules, including FGH10019 and betulin, that directly interact with the SREBP-SCAP complex and inhibit SREBP activation, improve lipid metabolism in vivo. 50 Pharmacological inhibition of SREBP migration might prove to 
be an effective approach for treating hyperlipidemia and associated metabolic diseases.

\section{PUFAs}

PUFAs have been reported to suppress hepatic SREBP-1c post${ }_{5}$ transcriptionally in addition to their effects on the SREBP synthesis. One possible mechanism by which PUFAs reduce lipid levels is inhibition of SREBP-1c maturation (Fig. 3). PUFAs, including eicosapentaenoic acid (Fig. 5), block the proteolytic processing of SREBP-1c and reduce amounts of the nuclear form 10 of SREBP-1c, both in cells and in vivo. ${ }^{73-75}$ Inhibition of SREBP1c processing might be due to the loss of SCAP and/or S1P, which are required for proteolytic activation of SREBP-1c. ${ }^{76}$ However, the mechanism by which eicosapentaenoic acid might induce the loss of SCAP and S1P remains unknown. On the other 15 hand, arachidonic acid has been reported to inhibit the proteasomal degradation of Insig-1, potentiating the ability of sterols to block the proteolytic activation of SREBP-1c. ${ }^{77}$

\section{PPAR $\alpha / \gamma$ agonists}

As mentioned earlier, PPAR $\alpha$ agonists modulate the synthesis of 20 SREBP through LXR activity. Interestingly, activation of PPAR $\alpha$ by Wy14,643 or clofibrate (another PPAR $\alpha$ agonist, Fig. 6) also promotes the expression of Insig-1/2, thereby decreasing nuclear levels of SREBP-1 and -2, and impairing lipid synthesis in Fao cells and rat liver. ${ }^{78,79}$

25 Glitazones, PPAR $\gamma$ agonists used in the treatment of type 2 diabetes mellitus, sensitize insulin response by promoting adipogenesis and glucose uptake. ${ }^{80}$ PPAR $\gamma$ agonists have also been reported to modulate the amount of the nuclear SREBPs (Fig. 3). Troglitazone (Fig. 10), a PPAR $\gamma$ agonist, reduces nuclear 30 levels of SREBP-2 in HepG2 and Caco-2 cells, thus, decreasing the expression of SREBP-2-responsive genes, including HMGCR and LDLR, without increasing the expression levels of Insig- $2 .{ }^{81}$ On the other hand, troglitazone promotes the expression of Insig1/-2a in Fao cells, reducing the nuclear abundance of SREBP-1c 35 and leading to a reduction in triglyceride synthesis. ${ }^{79}$ Pioglitazone (Fig. 10), another PPAR $\gamma$ agonist, completely repressed nuclear translocation of SREBP-1c in the liver of wild-type mice fed the methionine and choline-deficient (MCD) diet, preventing MCDinduced steatohepatitis by an unknown mechanism. ${ }^{82}$

40 Results of other research on PPAR agonists reveal some<smiles></smiles><smiles>CCc1ccc(CCOc2ccc(CC3SC(=O)NC3=O)cc2)nc1</smiles>

Fig. 10 Chemical structures of PPAR $\gamma$ agonists. discrepancies as with the effects on the synthesis of SREBP. Two studies reported that administration of clofibrate, fenofibrate 45 (another PPAR $\alpha$ agonist, Fig. 6), or troglitazone did not affect either the amount of nuclear SREBPs in mouse liver or the expression of SREBPs, Insigs, and SREBP target genes in the liver and adipose tissue of pigs. ${ }^{73,83}$ Another study reported that wild-type mice treated with Wy14,643 actually exhibited ${ }_{50}$ increased amounts of nuclear SREBP-1c and fatty acid synthesis in the liver. ${ }^{84}$ Inconsistent results of the effects on the amount of the nuclear SREBP would also be due to differences in the species and nutritional status of cells and animals used in the experiments. ${ }^{47,79}$ Thus, experimental effects of PPAR agonists on ${ }_{55}$ SREBPs should be interpreted with particular care.

\section{Inhibitors of the nuclear form of SREBP}

\section{mTORC1 inhibitors}

The nuclear translocation of SREBP is controlled by mTORC1 signaling pathway. Pharmacological inhibition of mTORC1 ${ }_{60}$ might impair the nuclear translocation of SREBP (Fig. 3). The best known inhibitor of mTORC1 is rapamycin (Fig. 11). Rapamycin binds to FKBP12, and the resulting complex binds to and inactivates mTORC1 ${ }^{85}$ Treatment of hepatocytes and several other cell systems with this natural product impairs the insulin${ }_{65}$ induced accumulation of nuclear SREBP-1, decreasing the expression levels of SREBP-responsive genes, including FAS and SCD-1 ${ }^{86,87}$ Similarly, in vivo administration of rapamycin blocks the diet-induced increase of hepatic SREBP-1c. ${ }^{87}$ Another known mTOR inhibitor is Torin1 (Fig. 11), a synthetic kinase inhibitor 70 that binds to the ATP-binding pocket of $\mathrm{mTOR}\left(\mathrm{IC}_{50}=2 \mathrm{nM}\right.$ for mTORC1 in cells). ${ }^{88,89}$ This selective mTOR inhibitor also decreases the expression of SREBP-responsive genes in NIH 3T3

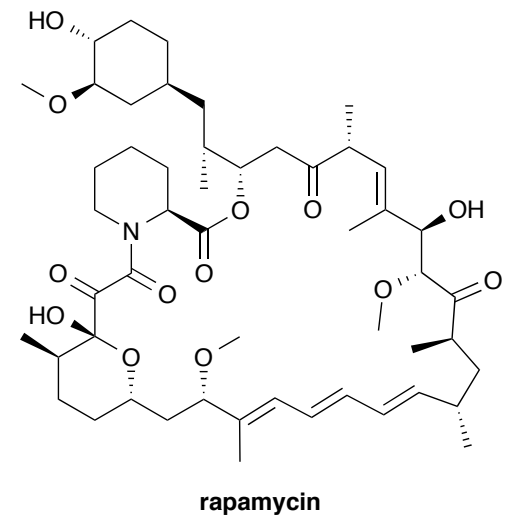<smiles>CCC(=O)N1CCN(c2ccc(-n3c(=O)ccc4cnc5ccc(-c6cnc7ccccc7c6)cc5c43)cc2C(F)(F)F)CC1</smiles>

Fig. 11 Chemical structures of mTORC1 inhibitors. 
<smiles>C=CCc1c(C2CC(=O)c3c(O)c(CC=C)c(O)c(CC=C)c3O2)ccc(OC)c1O</smiles><smiles>C[C@H]1C[C@H]2C(=O)C=C3OCO[C@@]34Oc3cc5c(cc3[C@@H]2[C@@H]14)OCO5</smiles>

sauchinone<smiles>CC1(C)C=Cc2c(ccc3c2OC[C@@H](c2ccc(O)cc2O)C3)O1</smiles>

glabridin<smiles>O=C(Nc1ccccc1-c1cn2c(CN3CCNCC3)csc2n1)c1cnc2ccccc2n1</smiles>

SRT1720

Fig. 12 Chemical structures of AMPK and SIRT1 activators.

cells, which rapamycin fails to do. ${ }^{23}$

\section{AMPK activators}

${ }_{5}$ Metformin (Fig. 12), an oral anti-diabetic drug in the biguanide class, activates AMPK. ${ }^{90}$ Metformin requires the kinase, LKB1, which phosphorylates and activates AMPK in the liver, and lowers blood glucose levels. ${ }^{91}$ Activation of AMPK mediates a reduction in expression of the hepatic gluconeogenic 10 genes, PEPCK and Glc-6-Pase. ${ }^{92}$ Metformin and other well known AMPK activators (Fig. 12), including 5-aminoimidazole4-carboxamide-1- $\beta$-D-ribofuranoside (AICAR), natural polyphenol resveratrol, and the synthetic polyphenol, S17834, inhibit the activation of SREBP-1c and -2 in cells and in vivo,

15 leading to the improvement of alcohol-induced fatty liver disease in rats or diet-induced fatty liver diseases in diabetic mouse models. ${ }^{28,90,93,94}$ The recently described AMPK activators, sauchinone and glabridin (Fig. 12), which are bioactive constituents of natural medicines, also suppress the expression

20 levels of SREBP-1c and decrease triglyceride levels in liver and white adipose tissue of high fat diet-induced obese mice. ${ }^{95,96}$

These observations collectively suggest the exciting possibility that small-molecule AMPK activators might provide a pharmacological means of suppressing SREBPs, thereby

25 impairing biosynthesis of fatty acids and cholesterols. A number of other AMPK activators have been discovered $;{ }^{97}$ however, their effects on SREBPs have not yet been investigated. Further research might lead to the discovery of clinically useful AMPK activators.

\section{${ }_{30}$ SIRT1 activators}

Small molecules that activate SIRT1, resveratrol and SRT1720 (Fig. 12), inhibit SREBPs in cells and in vivo, thereby decreasing levels of hepatic lipids and cholesterol, and improving alcoholic or non-alcoholic liver steatosis in mice. ${ }^{32,33,98}$ As discussed above,

35 resveratrol also activates AMPK, so that administration of resveratrol activates both SIRT1 and AMPK in mouse liver. ${ }^{98}$ Due to the crosstalk of SIRT1 and AMPK, it is unclear which factor is located upstream. ${ }^{99}$ Furthermore, although SRT1720 was originally discovered as an activator of SIRT $1,{ }^{100}$ its exact 40 mechanism of action remains under debate. ${ }^{101}$ Better understanding of the mechanisms by which resveratrol and SRT1720 activate SIRT1 and AMPK is required for the development of more effective drug-like activators. Nevertheless, it seems clear that small-molecule activators of AMPK and ${ }_{45}$ SIRT1 might serve as SREBP modulators.

\section{Drugs with unknown mechanisms}

A number of molecules have apparent indirect effects on SREBP expression through unknown mechanisms. For example, bortezomib (Fig. 13), a proteasome inhibitor used to treat 50 multiple myeloma, suppresses the mRNA expression of SREBP1c, thereby suppressing expression of downstream lipogenic genes and ultimately inhibiting alcohol-induced fatty liver. ${ }^{102}$ The detailed molecular mechanism of this surprising effect remains unclear; however, decreased expression of $\mathrm{C} / \mathrm{EBP} \alpha$, a 55 transcription factor upstream of SREBP, might partly be responsible for decreasing SREBP expression levels. On the other hand, pharmacological inhibition of proteasome has been reported to stabilize SREBPs, which are susceptible to ubiquitinproteasome degradation, ${ }^{103}$ and to increase expression levels of ${ }_{60}$ SREBP-responsive genes. ${ }^{103,104}$ The practical use of proteasome inhibitors for selective inhibition of SREBPs remains unclear and might not be appropriate for clinical applications.

Another example of a molecule that indirectly affects SREBP

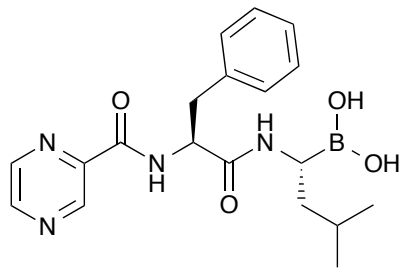

bortezomib

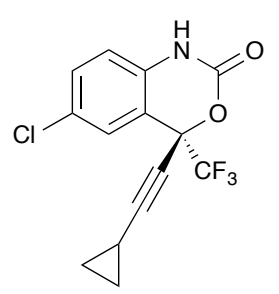

efavirenz
65 Fig. 13 Chemical structures of bortezomib and efavirenz 
<smiles>CCCCC[C@H](O)CC(=O)CCc1ccc(O)c(OC)c1</smiles><smiles>CCCCCC(O)CC(=O)NCc1ccc(O)c(OC)c1</smiles><smiles>COc1cc(CNC(=O)CCCC/C=C/C(C)C)ccc1O</smiles>

Fig. 14 Chemical structures of gingerol, 4 , and capsaicin.

expression is efavirenz (Fig. 13), a non-nucleoside reverse transcriptase inhibitor used clinically to treat HIV. Efavirenz 5 decreases levels of both SREBP-1c mRNA and its nuclear form in 3T3-L1 cells, reducing triglyceride accumulation during adipogenesis. ${ }^{105}$ Such SREBP inhibition is not observed with all non-nucleoside reverse transcriptase inhibitors, ${ }^{106}$ and the mechanism of efavirenz remains unknown.

10 A synthetic derivative of gingerol (Fig. 14), a bioactive natural product in ginger, provides another intriguing example. Ginger is used in natural medicine to treat a number of diseases, including diabetes, and an aqueous extract of ginger exhibited hypolipidaemic activity in rats. ${ }^{107}$ An amide derivative of 15 gingerol (4, Fig. 14) suppressed the expression of SREBP-1c in mouse liver, reducing the weight gain induced by high-fat diets. ${ }^{108}$ Similarly to capsaicin (Fig. 14), which has anti-obesity activity, gingerol is known to activate transient receptor potential vanilloid 1 (TRPV1). ${ }^{109,110}$ The effect of molecule 4 on TRPV1 is 20 unknown, and the relationship between TRPV1 and SREBP-1c remains unclear. However, further investigation of one or more of these molecules that indirectly affect SREBP expression could lead to new approaches for treating metabolic diseases.

\section{Conclusions}

${ }_{25}$ SREBP transcription factors have been widely investigated since their discovery twenty years ago. As master regulators of lipogenesis, SREBPs are likely to be key players in a broad range of signaling events. There is recent evidence that SREBPs play regulatory roles in a number of physiological processes, including 30 cancer growth, ER stress, immune response, and autophagy. ${ }^{14,21,22}$ However, despite increasing knowledge of their physiological roles in lipogenesis and their molecular interactions, the exact regulatory mechanisms of SREBPs in vivo remain unclear and merit further investigation. Small molecules that control SREBPs 35 would serve as useful tools to better understand the various roles of SREBPs, and to develop new pharmacological interventions for metabolic disorders and cancers.

\section{Acknowledgment}

The authors would like to thank Yuta Nakashima and Adil S.

40 Wakil for comments that have guided improvements to the manuscript. iCeMS is supported by World Premier International Research Center Initiative (WPI), MEXT, Japan.

\section{References}

Institute for Integrated Cell-Material Sciences (WPI-iCeMS) and Institute 45 for Chemical Research, Kyoto University, Uji, Kyoto 611-0011, Japan. Fax: +81 77438 3226; Tel: +81 77438 3225; E-mail: uesugi@scl.kyotou.ac.jp

1. M. S. Brown and J. L. Goldstein, Cell, 1997, 89, 331-340.

50 2. J. L. Goldstein, R. A. DeBose-Boyd and M. S. Brown, Cell, 2006, 124, 35-46.

3. M. H. Ahmed and C. D. Byrne, Drug Discov. Today, 2007, 12, 740747.

4. J. C. Cohen, J. D. Horton and H. H. Hobbs, Science, 2011, 332, $1519-1523$

5. T. Ide, H. Shimano, N. Yahagi, T. Matsuzaka, M. Nakakuki, T. Yamamoto, Y. Nakagawa, A. Takahashi, H. Suzuki, H. Sone, H. Toyoshima, A. Fukamizu and N. Yamada, Nat. Cell Biol., 2004, 6, 351-357.

60 6. Y.-A. Moon, G. Liang, X. Xie, M. Frank-Kamenetsky, K. Fitzgerald, V. Koteliansky, M. S. Brown, J. L. Goldstein and J. D. Horton, Cell Metab., 2012, 15, 240-246.

7. J. A. Menendez and R. Lupu, Nat. Rev. Cancer, 2007, 7, 763-777.

8. A. J. Brown, Biochem. J., 2008, 416, e15-17.

65 9. A. K. Walker and A. M. Naar, Clin Lipidol, 2012, 7, 27-36.

10. J. D. Horton, J. L. Goldstein and M. S. Brown, J. Clin. Invest., 2002, 109, 1125-1131.

11. T. F. Osborne, J. Biol. Chem., 2000, 275, 32379-32382.

12. T. Yoshikawa, H. Shimano, M. Amemiya-Kudo, N. Yahagi, A. H.

70 Hasty, T. Matsuzaka, H. Okazaki, Y. Tamura, Y. Iizuka, K. Ohashi, J. Osuga, K. Harada, T. Gotoda, S. Kimura, S. Ishibashi and N. Yamada, Mol. Cell. Biol., 2001, 21, 2991-3000.

13. G. Chen, G. Liang, J. Ou, J. L. Goldstein and M. S. Brown, Proc. Natl. Acad. Sci. U. S. A., 2004, 101, 11245-11250.

75 14. T. F. Osborne and P. J. Espenshade, Genes Dev., 2009, 23, 25782591.

15. R. B. Rawson, R. DeBose-Boyd, J. L. Goldstein and M. S. Brown, $J$. Biol. Chem., 1999, 274, 28549-28556.

16. M. Matsuda, B. S. Korn, R. E. Hammer, Y. A. Moon, R. Komuro, J. ${ }_{80}$ D. Horton, J. L. Goldstein, M. S. Brown and I. Shimomura, Genes Dev., 2001, 15, 1206-1216.

17. M. S. Brown and J. L. Goldstein, J. Lipid Res., 2009, 50 Suppl, S1527.

18. C. M. Adams, J. Reitz, J. K. De Brabander, J. D. Feramisco, L. Li, M.

85 S. Brown and J. L. Goldstein, J. Biol. Chem., 2004, 279, 5277252780 .

19. A. Radhakrishnan, Y. Ikeda, H. J. Kwon, M. S. Brown and J. L. Goldstein, Proc. Natl. Acad. Sci. U. S. A., 2007, 104, 6511-6518.

20. L. P. Sun, J. Seemann, J. L. Goldstein and M. S. Brown, Proc. Natl. Acad. Sci. U. S. A., 2007, 104, 6519-6526.

21. T. I. Jeon and T. F. Osborne, Trends Endocrinol. Metab., 2012, 23, 65-72.

22. W. Shao and P. J. Espenshade, Cell Metab., 2012, 16, 414-419.

23. T. R. Peterson, S. S. Sengupta, T. E. Harris, A. E. Carmack, S. A.

95 Kang, E. Balderas, D. A. Guertin, K. L. Madden, A. E. Carpenter, B. N. Finck and D. M. Sabatini, Cell, 2011, 146, 408-420.

24. J. L. Owen, Y. Zhang, S. H. Bae, M. S. Farooqi, G. Liang, R. E. Hammer, J. L. Goldstein and M. S. Brown, Proc. Natl. Acad. Sci. U. S. A., 2012, 109, 16184-16189.

100 25. B. B. Zhang, G. Zhou and C. Li, Cell Metab., 2009, 9, 407-416.

26. C. Canto and J. Auwerx, Cell. Mol. Life Sci., 2010, 67, 3407-3423.

27. M. Foretz, N. Ancellin, F. Andreelli, Y. Saintillan, P. Grondin, A. Kahn, B. Thorens, S. Vaulont and B. Viollet, Diabetes, 2005, 54, 1331-1339.

105 28. Y. Li, S. Xu, M. M. Mihaylova, B. Zheng, X. Hou, B. Jiang, O. Park, Z. Luo, E. Lefai, J. Y. Shyy, B. Gao, M. Wierzbicki, T. J. Verbeuren, 
R. J. Shaw, R. A. Cohen and M. Zang, Cell Metab., 2011, 13, 376388.

29. D. D. Sarbassov, S. M. Ali and D. M. Sabatini, Curr. Opin. Cell Biol., 2005, 17, 596-603

5 30. F. Yap, L. Craddock and J. Yang, Int J Biol Sci, 2011, 7, 645-650.

31. L. Guarente, Nature, 2006, 444, 868-874

32. B. Ponugoti, D. H. Kim, Z. Xiao, Z. Smith, J. Miao, M. Zang, S. Y. Wu, C. M. Chiang, T. D. Veenstra and J. K. Kemper, J. Biol. Chem., 2010, 285, 33959-33970

10 33. A. K. Walker, F. Yang, K. Jiang, J. Y. Ji, J. L. Watts, A Purushotham, O. Boss, M. L. Hirsch, S. Ribich, J. J. Smith, K. Israelian, C. H. Westphal, J. T. Rodgers, T. Shioda, S. L. Elson, P. Mulligan, H. Najafi-Shoushtari, J. C. Black, J. K. Thakur, L. C. Kadyk, J. R. Whetstine, R. Mostoslavsky, P. Puigserver, X. Li, N. J. Dyson, A. C. Hart and A. M. Naar, Genes Dev., 2010, 24, 1403-1417.

34. T. Uemura, T. Goto, M. S. Kang, N. Mizoguchi, S. Hirai, J. Y. Lee, Y. Nakano, J. Shono, S. Hoshino, K. Taketani, N. Tsuge, T. Narukami, M. Makishima, N. Takahashi and T. Kawada, J. Nutr., 2011, 141, 17-23.

20 35. W. J. Zuercher, R. G. Buckholz, N. Campobasso, J. L. Collins, C. M. Galardi, R. T. Gampe, S. M. Hyatt, S. L. Merrihew, J. T. Moore, J. A. Oplinger, P. R. Reid, P. K. Spearing, T. B. Stanley, E. L. Stewart and T. M. Willson, J. Med. Chem., 2010, 53, 3412-3416.

36. X. Jiao, D. J. Kopecky, B. Fisher, D. E. Piper, M. Labelle, S. McKendry, M. Harrison, S. Jones, J. Jaen, A. K. Shiau, P. Escaron, J. Danao, A. Chai, P. Coward and F. Kayser, Bioorg. Med. Chem. Lett., 2012, 22, 5966-5970.

37. D. B. Jump and S. D. Clarke, Annu. Rev. Nutr., 1999, 19,63-90.

38. J. Ou, H. Tu, B. Shan, A. Luk, R. A. DeBose-Boyd, Y. Bashmakov, J. L. Goldstein and M. S. Brown, Proc. Natl. Acad. Sci. U. S. A., 2001, 98, 6027-6032.

39. T. Yoshikawa, H. Shimano, N. Yahagi, T. Ide, M. Amemiya-Kudo, T. Matsuzaka, M. Nakakuki, S. Tomita, H. Okazaki, Y. Tamura, Y. Iizuka, K. Ohashi, A. Takahashi, H. Sone, J. Osuga Ji, T. Gotoda, S. Ishibashi and N. Yamada, J. Biol. Chem., 2002, 277, 1705-1711.

40. G. Howell, 3rd, X. Deng, C. Yellaturu, E. A. Park, H. G. Wilcox, R. Raghow and M. B. Elam, Biochim. Biophys. Acta, 2009, 1791, 11901196.

41. H. J. Kim, M. Takahashi and O. Ezaki, J. Biol. Chem., 1999, 274, $25892-25898$

42. M. Gottlicher, E. Widmark, Q. Li and J. A. Gustafsson, Proc. Natl. Acad. Sci. U. S. A., 1992, 89, 4653-4657.

43. P. G. Martin, H. Guillou, F. Lasserre, S. Dejean, A. Lan, J. M. Pascussi, M. Sancristobal, P. Legrand, P. Besse and T. Pineau, Hepatology, 2007, 45, 767-777.

44. R. Dentin, F. Benhamed, J. P. Pegorier, F. Foufelle, B. Viollet, S Vaulont, J. Girard and C. Postic, J. Clin. Invest., 2005, 115, 28432854.

45. S. Kersten, PPAR Res, 2008, 2008, 132960.

50 46. T. Yoshikawa, T. Ide, H. Shimano, N. Yahagi, M. Amemiya-Kudo, T. Matsuzaka, S. Yatoh, T. Kitamine, H. Okazaki, Y. Tamura, M. Sekiya, A. Takahashi, A. H. Hasty, R. Sato, H. Sone, J. Osuga, S. Ishibashi and N. Yamada, Mol. Endocrinol., 2003, 17, 1240-1254.

47. A. Fernandez-Alvarez, M. S. Alvarez, R. Gonzalez, C. Cucarella, J. Muntane and M. Casado, J. Biol. Chem., 2011, 286, 21466-21477.

48. C. Thomas, R. Pellicciari, M. Pruzanski, J. Auwerx and K. Schoonjans, Nat. Rev. Drug Discov., 2008, 7, 678-693.

49. T. Jiang, X. X. Wang, P. Scherzer, P. Wilson, J. Tallman, H Takahashi, J. Li, M. Iwahashi, E. Sutherland, L. Arend and M. Levi, Diabetes, 2007, 56, 2485-2493.

50. M. Watanabe, S. M. Houten, L. Wang, A. Moschetta, D. J. Mangelsdorf, R. A. Heyman, D. D. Moore and J. Auwerx, J. Clin. Invest., 2004, 113, 1408-1418.

51. G. J. Schroepfer, Jr., Physiol. Rev., 2000, 80, 361-554.

${ }_{65} 52$. B. A. Janowski, P. J. Willy, T. R. Devi, J. R. Falck and D. J. Mangelsdorf, Nature, 1996, 383, 728-731.

53. B. A. Janowski, M. J. Grogan, S. A. Jones, G. B. Wisely, S. A. Kliewer, E. J. Corey and D. J. Mangelsdorf, Proc. Natl. Acad. Sci. U. S. A., 1999, 96, 266-271.

70 54. W. Chen, G. Chen, D. L. Head, D. J. Mangelsdorf and D. W. Russell, Cell Metab., 2007, 5, 73-79.
55. J. J. Repa, G. Liang, J. Ou, Y. Bashmakov, J.-M. A. Lobaccaro, I. Shimomura, B. Shan, M. S. Brown, J. L. Goldstein and D. J. Mangelsdorf, Genes Dev., 2000, 14, 2819-2830.

75 56. J. Beltowski, Cardiovasc Ther, 2008, 26, 297-316.

57. J. Yang, J. L. Goldstein, R. E. Hammer, Y. A. Moon, M. S. Brown and J. D. Horton, Proc. Natl. Acad. Sci. U. S. A., 2001, 98, 1360713612.

58. T. Okada, K. Haze, S. Nadanaka, H. Yoshida, N. G. Seidah, Y.

80 Hirano, R. Sato, M. Negishi and K. Mori, J. Biol. Chem., 2003, 278, 31024-31032.

59. K. Bodvard, J. Mohlin and W. Knecht, Protein Expr Purif, 2007, 51, 308-319.

60. A. Pasquato, P. Pullikotil, M. C. Asselin, M. Vacatello, L. Paolillo, F. Ghezzo, F. Basso, C. Di Bello, M. Dettin and N. G. Seidah, J. Biol. Chem., 2006, 281, 23471-23481.

61. J. P. Gorski, N. T. Huffman, S. Chittur, R. J. Midura, C. Black, J. Oxford and N. G. Seidah, J. Biol. Chem., 2011, 286, 1836-1849.

62. B. A. Hay, B. Abrams, A. Y. Zumbrunn, J. J. Valentine, L. C. Warren, S. F. Petras, L. D. Shelly, A. Xia, A. H. Varghese, J. L. Hawkins, J. A. Van Camp, M. D. Robbins, K. Landschulz and H. J. Harwood, Jr., Bioorg. Med. Chem. Lett., 2007, 17, 4411-4414.

63. J. L. Hawkins, M. D. Robbins, L. C. Warren, D. Xia, S. F. Petras, J. J. Valentine, A. H. Varghese, I. K. Wang, T. A. Subashi, L. D. Shelly, B. A. Hay, K. T. Landschulz, K. F. Geoghegan and H. J. Harwood, Jr., J. Pharmacol. Exp. Ther., 2008, 326, 801-808.

64. L. Feng, H. Yan, Z. Wu, N. Yan, Z. Wang, P. D. Jeffrey and Y. Shi, Science, 2007, 318, 1608-1612.

65. M. Guan, K. Fousek, C. Jiang, S. Guo, T. Synold, B. Xi, C. C. Shih and W. A. Chow, Clin. Cancer. Res., 2011, 17, 1796-1806.

66. M. Guan, K. Fousek and W. A. Chow, FEBS J., 2012, 279, 23992411.

67. N. G. Seidah and A. Prat, Nature Reviews Drug Discovery, 2012, 11, 367-383.

10568 . J. M. Rojek, G. Pasqual, A. B. Sanchez, N. T. Nguyen, J. C. de la Torre and S. Kunz, J. Virol., 2010, 84, 573-584.

69. S. Kamisuki, Q. Mao, L. Abu-Elheiga, Z. Gu, A. Kugimiya, Y. Kwon, T. Shinohara, Y. Kawazoe, S. Sato, K. Asakura, H. Y. Choo, J. Sakai, S. J. Wakil and M. Uesugi, Chem. Biol., 2009, 16, 882-892.

110 70. J. J. Tang, J. G. Li, W. Qi, W. W. Qiu, P. S. Li, B. L. Li and B. L. Song, Cell Metab., 2011, 13, 44-56.

71. Y. Choi, Y. Kawazoe, K. Murakami, H. Misawa and M. Uesugi, $J$. Biol. Chem., 2003, 278, 7320-7324.

72. S. Kamisuki, T. Shirakawa, A. Kugimiya, L. Abu-Elheiga, H. Y. Choo, K. Yamada, H. Shimogawa, S. J. Wakil and M. Uesugi, J. Med. Chem., 2011, 54, 4923-4927.

73. N. Yahagi, H. Shimano, A. H. Hasty, M. Amemiya-Kudo, H. Okazaki, Y. Tamura, Y. Iizuka, F. Shionoiri, K. Ohashi, J. Osuga, K. Harada, T. Gotoda, R. Nagai, S. Ishibashi and N. Yamada, J. Biol. Chem., 1999, 274, 35840-35844.

74. V. C. Hannah, J. Ou, A. Luong, J. L. Goldstein and M. S. Brown, J. Biol. Chem., 2001, 276, 4365-4372.

75. Y. Takeuchi, N. Yahagi, Y. Izumida, M. Nishi, M. Kubota, Y. Teraoka, T. Yamamoto, T. Matsuzaka, Y. Nakagawa, M. Sekiya, Y. Iizuka, K. Ohashi, J. Osuga, T. Gotoda, S. Ishibashi, K. Itaka, K. Kataoka, R. Nagai, N. Yamada, T. Kadowaki and H. Shimano, J. Biol. Chem., 2010, 285, 11681-11691.

76. N. Tanaka, X. Zhang, E. Sugiyama, H. Kono, A. Horiuchi, T. Nakajima, H. Kanbe, E. Tanaka, F. J. Gonzalez and T. Aoyama, Biochem. Pharmacol., 2010, 80, 1601-1612.

77. J. N. Lee, X. Zhang, J. D. Feramisco, Y. Gong and J. Ye, J. Biol. Chem., 2008, 283, 33772-33783.

78. B. König, A. Koch, J. Spielmann, C. Hilgenfeld, G. I. Stangl and K. Eder, Biochem. Pharmacol., 2007, 73, 574-585.

35 79. B. König, A. Koch, J. Spielmann, C. Hilgenfeld, F. Hirche, G. I. Stangl and K. Eder, Eur. J. Pharmacol., 2009, 605, 23-30.

80. C. Knouff and J. Auwerx, Endocr. Rev., 2004, 25, 899-918.

81. A. Klopotek, F. Hirche and K. Eder, Exp Biol Med (Maywood), 2006 , 231, 1365-1372.

140 82. A. Da Silva Morais, V. Lebrun, J. Abarca-Quinones, S. Brichard, L. Hue, B. Guigas, B. Viollet and I. A. Leclercq, Journal of hepatology, 2009, 50, 489-500. 
83. S. Luci, B. Giemsa, H. Kluge and K. Eder, Am. J. Physiol. Regul. Integr. Comp. Physiol., 2007, 293, R70-77.

84. B. L. Knight, A. Hebbachi, D. Hauton, A. M. Brown, D. Wiggins, D. D. Patel and G. F. Gibbons, Biochem. J., 2005, 389, 413-421.

5 85. D. M. Sabatini, Nat. Rev. Cancer, 2006, 6, 729-734.

86. T. Porstmann, C. R. Santos, B. Griffiths, M. Cully, M. Wu, S Leevers, J. R. Griffiths, Y. L. Chung and A. Schulze, Cell Metab., $2008,8,224-236$

87. S. Li, M. S. Brown and J. L. Goldstein, Proc. Natl. Acad. Sci. U. S. A., 2010, 107, 3441-3446

88. C. C. Thoreen, S. A. Kang, J. W. Chang, Q. Liu, J. Zhang, Y. Gao, L. J. Reichling, T. Sim, D. M. Sabatini and N. S. Gray, J. Biol. Chem., 2009, 284, 8023-8032.

89. Q. Liu, J. W. Chang, J. Wang, S. A. Kang, C. C. Thoreen, A Markhard, W. Hur, J. Zhang, T. Sim, D. M. Sabatini and N. S. Gray, J. Med. Chem., 2010, 53, 7146-7155.

90. G. Zhou, R. Myers, Y. Li, Y. Chen, X. Shen, J. Fenyk-Melody, M. Wu, J. Ventre, T. Doebber, N. Fujii, N. Musi, M. F. Hirshman, L. J. Goodyear and D. E. Moller, J. Clin. Invest., 2001, 108, 1167-1174.

20 91. R. J. Shaw, K. A. Lamia, D. Vasquez, S. H. Koo, N. Bardeesy, R. A. Depinho, M. Montminy and L. C. Cantley, Science, 2005, 310, 16421646.

92. P. A. Lochhead, I. P. Salt, K. S. Walker, D. G. Hardie and C. Sutherland, Diabetes, 2000, 49, 896-903.

25 93. K. Tomita, G. Tamiya, S. Ando, N. Kitamura, H. Koizumi, S. Kato, Y. Horie, T. Kaneko, T. Azuma, H. Nagata, H. Ishii and T. Hibi, Alcoholism: Clinical and Experimental Research, 2005, 29, 240S245S.

94. J. Yang, L. Craddock, S. Hong and Z. M. Liu, J. Cell. Biochem., 2009, 106, 414-426.

95. Y. W. Kim, Y. M. Kim, Y. M. Yang, T. H. Kim, S. J. Hwang, J. R. Lee, S. C. Kim and S. G. Kim, Free Radic Biol Med, 2010, 48, 567578 .

96. J. W. Lee, S. S. Choe, H. Jang, J. Kim, H. W. Jeong, H. Jo, K. H. Jeong, S. Tadi, M. G. Park, T. H. Kwak, J. Man Kim, D. H. Hyun and J. B. Kim, J. Lipid Res., 2012, 53, 1277-1286.

97. L. F. Yu, B. Y. Qiu, F. J. Nan and J. Li, Curr. Top. Med. Chem., 2010, 10, 397-410.

98. J. M. Ajmo, X. Liang, C. Q. Rogers, B. Pennock and M. You, $A m J$ Physiol Gastrointest Liver Physiol, 2008, 295, G833-842.

99 J. H. Chung, V. Manganiello and J. R. Dyck, Trends Cell Biol., 2012, 22, 546-554.

100 J. C. Milne, P. D. Lambert, S. Schenk, D. P. Carney, J. J. Smith, D. J. Gagne, L. Jin, O. Boss, R. B. Perni, C. B. Vu, J. E. Bemis, R. Xie, J.

$45 \quad$ S. Disch, P. Y. Ng, J. J. Nunes, A. V. Lynch, H. Yang, H. Galonek, K. Israelian, W. Choy, A. Iffland, S. Lavu, O. Medvedik, D. A. Sinclair, J. M. Olefsky, M. R. Jirousek, P. J. Elliott and C. H. Westphal, Nature, 2007, 450, 712-716.

101 J. A. Baur, Z. Ungvari, R. K. Minor, D. G. Le Couteur and R. de Cabo, Nat. Rev. Drug Discov., 2012, 11, 443-461.

102 J. Oliva, S. W. French, J. Li and F. Bardag-Gorce, Exp Mol Pathol, 2012, 93, 26-34.

103 Y. Hirano, M. Yoshida, M. Shimizu and R. Sato, J. Biol. Chem., 2001, 276, 36431-36437.

55104 D. J. Kuhn, A. C. Burns, A. Kazi and Q. P. Dou, Biochim. Biophys. Acta, 2004, 1682, 1-10.

105 K. El Hadri, M. Glorian, C. Monsempes, M. N. Dieudonne, R. Pecquery, Y. Giudicelli, M. Andreani, I. Dugail and B. Feve, J. Biol. Chem., 2004, 279, 15130-15141.

60106 J. Diaz-Delfin, M. del Mar Gutierrez, J. M. Gallego-Escuredo, J. C. Domingo, M. Gracia Mateo, F. Villarroya, P. Domingo and M. Giralt, Antiviral Res., 2011, 91, 112-119.

107 Z. M. Al-Amin, M. Thomson, K. K. Al-Qattan, R. Peltonen-Shalaby and M. Ali, The British journal of nutrition, 2006, 96, 660-666.

65108 M. Okamoto, H. Irii, Y. Tahara, H. Ishii, A. Hirao, H. Udagawa, M. Hiramoto, K. Yasuda, A. Takanishi, S. Shibata and I. Shimizu, $J$. Med. Chem., 2011, 54, 6295-6304.

109 Y. Iwasaki, A. Morita, T. Iwasawa, K. Kobata, Y. Sekiwa, Y. Morimitsu, K. Kubota and T. Watanabe, Nutr. Neurosci., 2006, 9, 169-178.

110 X. J. Luo, J. Peng and Y. J. Li, Eur. J. Pharmacol., 2011, 650, 1-7. 